\title{
Interdependențele conduitei bilingve. Profilul psiho-sociolingvistic al bilingvismului maghiar-român
}

\author{
Erika-Mária Tódor* \\ Facultatea de Științe Economice și Umaniste, Universitatea Sapientia, Piața Libertății 1, 530104 Miercurea Ciuc, România
}

\section{Despre articol}

Istoric:

Primit 6 martie 2015

Acceptat 30 aprilie 2015

Publicat 17 iulie 2015

Cuvinte-cheie:

limba română ne-maternă

bilingvism

interferență lingvistică

contact lingvistic

conduită verbală

\begin{abstract}
Rezumat
Lucrarea de față are ca punct de plecare prezentarea specificului unei populații școlare din România pentru care limba română reprezintă limba ne-maternă, limba maternă fiind limba maghiară. Prima parte a lucrării oferă o caracterizare succintă a formelor de bilingvism care pot fi identificate în contextul acestei populații. Această subtemă va aborda, pe de o parte, coordonatele lingvistice ale profilului subiectului bilingv studiat de noi (interferența lingvistică, calcul lingvistic, pseudo-creativitatea lingvistică etc.), iar, pe de altă parte, va oferi o prezentare a principalelor dimensiuni socio-afective ale conduitei verbale (cum ar fi, angoasa comunicațională, refularea intenției de comunicare, schimbarea de cod lingvistic etc.). Aceste caracteristici, în configurația lor specifică, pot fi urmărite și în contextul altor vorbitori bi(multi)lingvi. Partea a doua a lucrării cuprinde descrierea unor strategii de activare a vocabularului în cazul persoanelor bilingve prin raportare la varietatea contextelor de comunicare.

Constatările, observațiile formulate reprezintă o sinteză a cercetărilor empirice desfășurate în anii anteriori (2000-2013) prin metode diferite de cercetare, cum ar fi: observația, studiul de caz, interviul structurat, chestionarea. Lucrarea îşi propune să ofere o imagine globală asupra unei configuraţii specifice de manifestare a bilingvismului.
\end{abstract}

\section{Preambul}

În cadrul acestei lucrări am propus redefinirea tiparelor conduitei verbale manifestate în contextul unei configurații specifice a factorilor intra- și extralingvistici ai bilingvismului, și anume, în cazul populației școlare maghiare din România. Premisele pe care se fundamentează această analiză relevă fidel rațiunea re-lecturii și implicit a re-dimensionării coordonatelor care definesc profilul psiholingvistic al vorbitorului bilingv.

Descrierile apărute pînă acum (Ádám, 1993; Hazy, 1999), care tratează fenomenele contactelor lingvistice în cazul limbilor maghiară şi română, au avut în vedere, în primul rînd, dimensiunea structurală a interrelației lingvistice, organizarea structurilor lingvistice și analiza contrastivă a faptelor de limbă. Perspectiva istorică asupra contactului lingvistic și cultural o regăsim în analizele etimologice (referitoare la secolele XIV-XVI) ale maghiarismelor apărute în textele culte traduse în limba română (Gafton, 2001; Pál, 2014). Cercetările centrate pe interdependența factorilor structurali și non-structurali sînt mult mai puține (Horváth, 2008) și tratează modul de relaționare prin limbă a individului la mediul social apropiat şi depărtat. Considerăm că descrierea conduitei verbale bilingve trebuie tratată în multidimensionalitatea ei, dintr-o perspectivă holistică, prin luarea în considerare a complementarității factorilor structurali și non-structurali, a abordărilor lingvistice şi extralingvitice, prin studiul modului de A FI, de A EXISTA al individului în limbă/limbi, căci numai astfel putem obține o imagine mai nuanțată a profilului vorbitorului bilingv. Interdependețele, contactele lingvistice, ca aspecte ale contactelor culturale, pot fi înțelese „doar într-un context psihologic și sociocultural cuprinzător..." (Weinreich, 2013, p. 5.)

*Adresă de corespondență: todor.erika@yahoo.com. 
De asemenea, fenomenele privind contactele lingvistice, pe care nu le putem aborda în afara contactelor culturale, trebuie tratate în dinamismul lor și prin raportare la „spiritul veacului” (termen lovinescian) reflectat în limbă. Democratizarea scrisului, răspîndirea comunicării electronice, generalizarea scrierii rapide, abreviate, a lecturii fragmentate, omniprezența formelor colocviale și argotice, prezența anglicanismelor, a calcurilor, lipsa de respect pentru formă, neglijența generalizată etc. sînt doar cîteva indicii ale Prezentului, supuse reflecției de Zafiu (2010). Asistăm, practic, la înlocuirea reziduurilor sloganelor comuniste cu cele ale Prezentului, iar tendințele socio-culturale dominante-comune în cazul ambelor limbi în discuție-îşi pun o amprentă globală, asupra manifestărilor verbale ale individului bi(multi)lingv, indiferent de codul lingvistic ales pentru exprimarea Sinelui. Astfel, „spiritul veacului” are un impact modelator atît asupra individului vorbitor-receptor, cît și aspura fenomenelor de interinfluență lingvistică. Acest lucru implică chiar și faptul că unele tipuri de interferențe predominante într-o epocă sau într-o perioadă a achiziției lingvistice pot deveni mai puțin pronunțate sau chiar pot dispărea, după cum alte fenomene (cum ar fi interferențele stilistice, interferențele cu L3 etc.) noi le pot lua locul.

Lucrarea de față își propune să readucă în atenție, dintr-o perspectivă pînă acum mai puțin abordată, problematica individului bilingv aflat sub impactul modelator al globalizării, și încearcă să ofere o abordare integrată asupra unei configurații specifice de bilingvism. În cadrul acestei lucrări vom prezenta aspectele generale ale profilului individului bi(multi)lingv, iar exemplele ilustrative le vom aduce dintr-un domeniu abordat în studiile noastre, domeniul bilingvismului româno-maghiar.

\section{Caracterizare generală}

Întîlnirea, contactul dintre diferite universuri lingvistice și de gîndire, precum și dinamica proprie a acestora au repercusiuni semnificative asupra fiecărei limbi şi culturi aflate în contact. O consecinţă firească a contactului lingvistic o reprezintă formele mai simple sau mai complexe de manifestare ale interferenței. Interferența apare atunci cînd vorbitorul bilingv echivalează un fapt lingvistic din sistemul secundar cu unul din sistemul primar, transferîndu-l, integrîndu-l în codul lingvistic activat (Weinreich, 2013). Acest fenomen-remarcă Gafton (2010, p. 78) —,,nu se referă în mod exclusiv la materialul lingvistic și conceptual, ci poate include chiar unele dintre înseși regulile de funcționare a sistemului”.

Configurația fiecărei categorii de interferențe este determinată de o serie de factori, dintre care semnalăm doar cîțiva: modul de însușire a limbii, vîrsta achiziției, experiențele glotologice anterioare ale individului, contextele/situațiile de folosire a limbii, experiențele gnoseologice cu care se asociează, motivația învățării etc. Cunoașterea acestei configurații, precum și a manifestării ei în conduita vorbitorului reprezintă subaspecte importante ale profilului unui vorbitor, fiind tipare de deschidere spre definirea modului de fi într-o limbă sau într-alta. De aceea considerăm că, dincolo de studiul aspectelor generale ale interinfluențelor culturale și lingvistice, devine importantă și manifestarea lor specifică.

\section{Metodele de cercetare ale conduitei verbale}

Elementele centrale ale descrierii fenomenelor interlingvistice le-au constituit observarea vorbitorului bilingv în praxisului comunicării și urmărirea modului acestuia de manifestare în cadrul a două tipare lingvistice (și culturale). Prin contact, vorbitorul face cunoștință „cu elementele unui nou sistem lingvistic, cu modalitățile acestuia de a funcționa, cu regulile care îl guvernează, cu mentalitățile pe care le vehiculează, promovează și plăsmuiește” (Gafton, 2010, p. 82), iar realizarea interdependențelor lingvistice nu se înscrie în categoria preocupărilor conștiente, fiind vorba, mai degrabă, de o tendință naturală de a activa elementele, tiparele lingvistice aflate la îndemînă, de dorința de a-lînțelege pe Celălalt și a se face de înțeles.

Vom avea în vedere, în cele ce urmează, cele două limbi (adică limba maternă și o limbă ne-maternăํ),

\footnotetext{
${ }^{1}$ Prin denumirea de limbă ne-maternă, desemnăm statutul limbii și înțelegem prin ea faptul că este vorba de o limbă însușită după limba maternă, fiind o limbă prezentă (în grade diferite) în mediul socio-cultural al individului (fiind vorba de limbă de stat). „... Este a doua limbă din punctul de vedere al ordinii în care copilul o învață și al non-identităţii cu limba de predare... și prima limbă din punct de vedere socio-politic" (Pamfil, 2000, p. 12).
} 
și ne vom raporta doar tangențial la faptul că vorbitorii analizați studiază paralel, sub diferite forme, și alte limbi străine. Scopul primordial al lucrării îl constituie inventarierea acelor dominante (sau pattern-uri) lingvistice, care sînt prezente în conduita verbală a indivizilor studiaţi și care, în mod cert, reapar într-o manieră specifică, și în cazul altor forme de manifestare bilingvă.

În cazul manifestării bilingve studiate de noi, conform cercetărilor socio-lingvistice efectuate în domeniu (Horváth, 2008), distingem următoarele forme dominante de manifestare: a) bilingvismul simetric (echilibrat sau ambilingvism), b) asimetric (neechilibrat), respectiv c) bilingvismul substractiv. Observațiile formulate în continuare au ca punct de pornire aceste forme de bilingvism, iar datele prezentate sînt selectate din cercetările empirice desfăşutate în anii anteriori (2000-2013), prin metode diferite de cercetare, cum ar fi: observația, studiul de caz (în contextul datelor referitoare la profilul conduitei verbale), interviul structurat, chestionarea (în cazul studiului peisajului lingvistic).

\section{Interferențele și vorbirea}

Prin fenomenul interferenței înțelegem transferul negativ al structurilor fixate-de cele mai multe ori-în limba de bază (maternă) a vorbitorului, manifestîndu-se în tendința acestuia de echivalare și de substituire a unui fapt lingvistic fixat într-un sistem lingvistic cu unul propriu celuilalt sistem. În cazul bilingvismului maghiar-român, asistăm, din punct de vedere structural, la întîlnirea a două sisteme lingvistice diferite: una aglutinantă, cealaltă flexionară (analitică). Acest fenomen vizează toate compartimentele sistemului lingvistic, cu alte cuvinte, observăm prezența interferențelor fonetice, grafice, de la nivelul unităților suprasegmentale, interferențe morfo-sintactice, lexico-semantice, stilistice etc. ceea ce constituie gama largă a greșelilor interlingvistice. Pe baza unui studiu anterior (Tódor, 2005, p. 137-148), cele mai frecvente greșeli (datorate interferenței lingvistice) care apar în exprimarea elevilor din școlile cu limba de predare maghiară sînt: greșeli de acord, de folosire a pronumelui personal și a celui reflexiv, a prepoziției, greșeli de pronunție și accent, precum și greșelile lexico-semantice.

Fără a avea pretenția unei prezentări exhaustive, vom ilustra în continuare, prin cîteva exemple, fenomenele amintite:

(a) interferențe fonetice: articularea sunetelor $[\breve{a}],[\hat{\imath}(\hat{a})]$, după modelul articulator al unor sunete cu pronunție asemănătoare din limba maghiară $[\ddot{o}],[\ddot{u}]$; pronunția postpalatală a sunetelor $\left[k^{\prime}\right],[\dot{g}],[\check{c}],[\breve{g}]$, sau pronunția accentuată, separată a sunetelor din diftongi și triftongi etc.

Trebuie remarcat faptul că, la nivelul interferenței fonetice, există unele fenomene care, pe baza observațiilor noastre, capătă manifestări mai puțin pronunțate în cazul studiului timpuriu al limbii engleze. Astfel este cazul sunetului $e$, pronunțat mai deschis în unele cuvinte (de exemplu în: citeşte, $c e$ etc.) de către vorbitorii maghiari, însă sub influența limbii a treia pronunția interferențială devine mai puțin observabilă. De asemenea, modul învățării poate induce anumite tipuri de interferențe. Atunci cînd învățarea pronunției se realizează predominant pe cale livrescă, confuzia în pronunția sunetelor $[i]$, [îl] devine mai accentuată (de exemplu: împărat/impărat), față de situațiile de învăţare centrate pe comunicare și suport auditiv.

(b) interferențe grafice: Se concretizează în apariția unor confuzii în scrierea literelor $[c],[s],[j]$, care au alte corespondențe fonetice în limba maternă;

(c) interferențe de accent: Se manifestă în tendința de a marca accentul în cazul cuvintelor românești pe prima silabă, așa cum se manifestă acest fenomen în limba de bază a vorbitorilor, unde accentul este fix;

(d) interferențe morfo-sintactice: Această categorie include o gamă largă a concretizărilor, cum ar fi: omiterea marcării acordului substantivului cu adjectivul în gen, număr și caz (de ex.: case mare în loc de case mari) sau nerealizarea acordului între subiect și predicat (de ex.: Ea învăţ în loc de Ea învață); folosirea inadecvată a formelor accentuate și neaccentuate ale pronumelui personal și reflexiv (de ex.: „El gîndește”, „A înserat"), greșeli în exprimarea raporturilor dintre acțiune-obiect (de ex.: Am dat pentru Ana) etc. Acest ultim aspect se explică prin faptul că în maghiară pentru exprimarea acestui tip 
de conținut se folosesc sufixe sau postpoziții, iar în română prepoziții, și, astfel, cele două limbi induc sau reflectă articulări specifice ale realității. Astfel, un vorbitor maghiar, de exemplu, se îndrăgostește in cineva, nu de cineva.

Interferențele de structură reprezintă o dimensiune mai stabilă și previzibilă, ca atare și posibilele greșeli interlingvistice pot fi identificate, prevenite și chiar ameliorate.

\section{Interferențe lexico-sematice}

Vocabularul este considerat de Al. Graur ca fiind „partea cea mai mobilă a limbii, pentru că e strîns legat de evoluția societății” (Graur, 1968, p. 271), iar sensul lexical este „mult mai încărcat de gîndire și mai puțin supus imperiului formei” (Gafton, 2010, p. 81). De aceea, interferența lexico-semantică trebuie văzută ca un fenomen mult mai complex și mai dinamic, datorită faptului că sinonimia interlingvistică „totală” este un fenomen relativ restrîns, iar relativismul lingvistic (adică articularea diferită a realității prin/în limbi diferite) implică formulări specifice. Iată cîteva exemple ilustrative. În limba maghiară (Hazy, 1999, p. 38), punctul de pornire al denumirii diferitelor subspecii de arbori e fructul + cuvîntul fa, în română fructul e derivat logic și gramatical al pomului: nuc-nucă, păr-pară, nu există pom de păr sau lemn de nucă. În contextul căutării corespondențelor, se poate întîmpla (Szilágyi, 1996) ca un concept—cum ar fi cuvîntul românesc sfeclă de zahăr (lat. Beta vulgaris) respectiv corespondentul maghiar cukorrépa-într-o limbă să apară într-o anumită categorie-gen, iar în cealaltă limbă în alta.

De asemenea, termenii de înrudire prezintă sensuri fie mai restrînse, fie mai cuprinzătoare în cele două limbi. Astfel, în limba maghiară apar două cuvinte pentru a desemna conceptul 'frate': (1) öccs (frate mic), și (2) bátya (frate mare); iar pentru cuvîntul rom. 'soră' limba maghiară întrebuințează termeni specializați pentru marcarea vîrstei, hug (soră mai mică), néne (soră mai mare).

Hazy (1999, p. 37) distinge situații de sinonimie interlingvistică totală și situații de sinonimie parțială. Primul aspect se referă la situațiile cînd cuvintele din limba A și B au o structură semantică și morfematică identică și complexe sonore diferite. De exemplu: udvar-curte, vin-bor. Cel de-al doilea caz vizează contextele în care un cuvînt din limba A poate să aibă o altă sferă semantică decît cuvîntul din limba B. Aşa cum remarcă autorul citat, de exemplu: cuvîntul süt din limba maghiară nu e sinonim „perfect” cu nici unul din seria a coace, a frige, a prăji, ci el înglobează sensurile cuprinse în cele trei corespondente românești, sau verbul mérni, din limba maghiară, are sensul de a măsura (dimensiunile) și de a cîntări (greutatea). De aceea se poate întîmpla ca unui vorbitor începător de limba română, rugămintea „Te rog să măsori fructele!” să nu i se pară incorectă.

O categorie aparte o reprezintă situaţia structurilor, expresiilor, frazemelor intraductibile pentru exprimarea cărora este nevoie de căutarea corespondențelor, a echivalențelor presupuse. Aceste structuri vizează, în special, sfera erudiției paremiologice, dar nu numai. Iată cîteva exemple ilustrative: „A tăia frunze la cîini”, „Munca e blagoslovită, cu ea ții de pită”.

O problemă specială o reprezintă cuvintele care, într-o limbă sau în alta, sînt polisemantice. Astfel este situația cuvintelor a vedea, a se uita sau a auzi și a asculta, a iubi, a-i plăcea, fiecare avînd referenți specifici în cele două limbi. În absența specificării sensurilor actualizate în contexte diferite, putem avea producții verbale de tipul: eu văd televizorul / aud radioul / iubesc muzica populară / cărțile care mă iubesc (în loc de cărțile care îmi plac) etc.

În această categorie putem include situația unor dublete lexicale și contextele lor de folosire corespunzătoare. Este vorba de cuvinte precum vreme/timp; nevastă/soție; a spune/a zice etc. Utilizarea adecvată a acestor cuvinte presupune un nivel mai profund de cunoaștere a limbii, ceea ce implică gîndirea în limba respectivă (Hazy, 1999, p. 22).

Însușirea limbii presupune ,intercunoaștere”, adică înțelegerea formelor existențiale specifice culturii Celuilalt. Pătrunderea parțială a acestor moduri existențiale generează, de asemenea, interferențele culturale prezente în profilul persoanei bilingve. În contextul bilingvismului studiat de noi, vom ilustra acest fenomen prin preferința unor vorbitori maghiari de a ura „Paște fericit!”, în loc de „-Hristos a-nviat! / 
-Adevărat a-nviat!", act lingvistic care se datorează absenței sale din cultura de bază a vorbitorului. Contexte asemănătoare şi dificultăți de stabilire a corespondențelor apar şi în cazul obiceiurilor specifice laice (colindatul, plugușorul etc) și religioase, în cazul obiceiurilor de trecere (nuntă, botez, înmormîntarea) precum și în cazul cuvintelor, expresiilor specific românești (dor, ie, ispită etc). Așa cum remarcă Noica (1987), aceste cuvinte, „fac aurul limbilor”, căci „în zona aceasta a cuvintului, unde nu încape întotdeauna comunicare, este totuși loc pentru o înțelegere mai intimă” (Noica, 1987, p. 208). Considerăm că identificarea acestor aspecte poate oferi repere importante pentru proiectarea demersului achizițional al limbii.

\section{6. „Cuvintele” și „necuvintele” în căutarea cuvîntului potrivit}

Producerea mesajelor într-o limbă diferită de cea maternă reprezintă, în special în etapa inițială şi intermediară a achiziției, un proces complex de activare a lexiconului mental al individului (Gósy, 2005), de căutare a cuvîntului potrivit pentru verbalizarea intenției de comunicare. Caracterul complex al acestei căutări capătă relevanță prin abordarea oferită de François Grosjean, conform căruia „vorbitorii bilingvi au două sisteme lingvistice independente şi interdependente în acelaşi timp” (online; traducere personală), în sensul că în procesarea căutării-reactivării cuvintelor, sintagmelor etc., ambele limbi sînt prezente, dar una, cea utilizată pentru transmiterea intenției comunicării într-o situație dată este mai pronunțat prezentă/activizată decît cealaltă (Grosjean, 1982).

În verbalizarea intenției de comunicare, cercetările de psiholingvistică (Levelt, 1989 apud Gósy, 2005) disting două momente majore ale realizării vorbirii: stadiul pre-verbal al comunicării şi stadiul verbalizării, adică cel al alegerii registrelor lingvistice şi al normelor de folosire a limbii. În armonizarea celor două etape decizionale pot apărea dificultăţi specifice atît în cazul vorbitorilor nativi, cît şi ai celor non-nativi. În cazul subiecților observați de noi, constatăm (în ultima vreme), în special în etapa de început a învăţării limbii, o încetinire a formulării mesajelor (aspecte prezentate pe larg în Tódor, 2009, p. 81), prezența pauzelor (de gîndire), apariția unor ticuri verbale (cum ar fi: hát (cuvînt maghiar), deci, apoi, etc.) Considerăm că aceste manifestări ale conduitei verbale reprezintă niște tehnici compensatorii pentru căutarea cuvîntului portivit.

În producerea mesajelor, adeseori apare fenomenul hiatusului lexical („necuvintele”), adică necunoașterea cuvîntului sau nesiguranța alegerii cuvîntului potrivit. În acest caz, cele mai frecrente mecanisme activate ca răspuns la completarea lacunelor lexicale sînt:

(a) pseudo-creativitatea lingvistică sau creativitate prin analogie, situații în care se creează cuvinte noi pe baza modelelor lingvistice existente. De exemplu: reproducăm pentru 'reproducem' (după modelul lucrăm, învățăm etc.), succesuri pentru 'succese' (după modelul lucruri, gînduri etc);

(b) adoptarea cuvintului din limba maternă (de exemplu: canal pentru 'lingură pe baza unui complex sonor asemănător din limba maternă: kanál);

(c) calcul lingvistic, adică traducerea „mimetică” (termen folosit într-un alt context de Nicolae \& Dragomirescu, 2011, p. 31) a cuvîntului. De exemplu: băț de pescuit 'undiță', cf. magh. halászbot, merge afară 'iese', cf. magh. kimegy.

Folosirea sensului potrivit, în contextul potrivit reprezintă o altă dimensiune a activării lexiconului mental. În acest caz, este foarte importantă cunoașterea nuanțelor semantice ale cuvintelor, deoarece, altfel, se poate ajunge la situații controversate, care îngreunează înțelegerea. De exemplu: „ne uităm (în loc de privim) la operă de la o distanță..., , „cerere rejectată” (în loc de respinsă), „audiez (în loc de ascult) radioul”.

Prezența calcului lingvistic generează, în cazul subiecților studiați de noi, o redusă sensibilitate față de pleonasme, căci în limba de bază, direcția, coordonatele acțiunii se exprimă prin prefixe, care, evident, sînt transferate prin traducere și în limba a doua. Astfel, pleonasmele de tipul a coborî̀ jos, a merge sus, a intra inăuntru etc. se datorează, în primul rînd, traducerii din limba de bază. 


\section{Conduita verbală}

Însușirea unei limbi nu constă doar în achiziția vocabularului și a normelor de folosire a acestuia, ci implică formarea unei culturi comunicaționale, care presupune inter-cunoaștere, înțelegerea articulării lumii în contextul alterității Celuilalt.

În conduita verbală a individului bilingv, în funcție de strategia de predare-învăţare, de contextul însușirii și al activării limbilor, apar diverse manifestări ale conduitei verbale, recunoașterea, identificarea cărora poate reprezenta un mijloc de autoeducare a conduitei verbale. Prezentăm, în continuare, cîteva dintre manifestările observate de noi (prezentate în Tódor, 2005, p. 156):

(a) Anxietatea/angoasa comunicațională constă în teama de a vorbi pentru a nu greși. Aceste manifestări ale conduitei verbale adeseori sînt rezultatul unor situații de predare-învățare predominant formale (cazul bilingvismului instituțional), al strategiilor de învățare centrate (predominant) pe formă și nu pe verbalizarea intenției de comunicare. Se concretizează, pe de o parte, în „retragerea în tăcere” a individului, iar, pe de altă parte, în exprimarea schematică, reducționistă a ideilor, a gîndurilor. Contextele de acest tip înglobează cumulul „greșelilor implicite" (Corder, 1981), ansamblul cuvintelor și al ideilor ne-spuse, care, din perspectiva cadrului didactic, ar putea reprezenta panorama indiciilor și a surselor de învăţare.

(b) Restructurarea intenției de comunicare in funcție de registrul lexical avut la dispoziție:

„... am vrut să spun un banc, dar n-aș fi putut... am renunțat” (elev, cls. X., 2001);

"Cînd vorbesc la telefon, de exemplu, vorbesc mai greu [româneşte]... dar cuvintele legate de administrație le ştiu mai ales româneşte...” (secretară, 2014).

Contextele de mai sus ilustrează stăpînirea adecvată doar a anumitor registre lingvistice, ceea ce implică folosirea nesigură a celorlalte registre. Aceste situații sînt specifice bilingvismului asimetric, instituțional şi ilustrează exersarea „parțială” a registrelor lingvistice (predominat formale), într-un context achizițional centrat mai ales pe performanță, nu pe competență.

(c) Schimbarea codului lingvistic

Fenomenul de schimbare a codului lingvistic, în cazul subiecților studiați de noi, reprezintă o manifestare a conduitei verbale, constînd în activarea, inserția unor structuri dintr-o limbă (în acest caz, din limba maternă) diferită de limba de bază (în acest caz, limba română) a comunicării (de exemplu: Am vrut să scriu despre naplemente [amurg]).

Acest fenomen diferă de mixarea/amestecul limbilor (activarea nediferențiată a limbilor), în primul rînd, prin intensitatea manifestării coprezenței celor două limbi (Benő, 2008). Schimbările interlingvistice de cod pot viza diferitele niveluri ale sistemului lingvistic (afixe, lexeme, sintagme, propoziții, expresii etc), iar în cazul celor care învaţă o limbă, ele sînt generate (de cele mai multe ori) de hiatusul lexical sau al registrului lingvistic. În orele de însușire a limbii, aceste fenomene pot fi creativ integrate şi valorificate ca surse de învăţare, de aceea este foarte important ca în educarea conduitei profesorului de limbă să se acorde atenție formării deprinderilor de monitorizare a acestor situații.

\section{Dubla natură a interinfluențelor lingvistice}

Contactul lingvistic, care reprezintă, de fapt, o dimensiune a contactului cultural, nu acționează unidirecțional. Interferența lingvistică este rodul interdependențelor, al influențelor reciproce, iar configurația și specificul ei sînt determinate de coordonatele contextului socio-economic, cultural și chiar politic. În conservarea sau schimbarea unei practici culturale sau lingvistice, este decisivă măsura în care practica a devenit sau nu „parte integrantă a unui sistem organizat de idei şi sentimente: măsura în care ea se împletește cu alte elemente de structură mai vastă” (Linton apud Weinreich, 2013, p. 7). Tocmai datorită practicii comune, amintite mai sus, fenomenele de contact lingvistic sînt prezente, în mod evident cu o pondere diferită şi în exprimarea în limba maternă a vorbitorilor maghiari. 
Cercetările efectuate în acest domeniu relevă faptul că, odată cu folosirea limbii române în contexte variate de viață (de exemplu: în diferite medii sociale, la locul de muncă, la școală etc.), ponderea lexemelor și a structurilor preluate din această limbă poate deveni mai semnificativă. Interferența ,retroactivă”, în acest caz, se poate observa la diferitele niveluri ale sistemului lingvistic, după cum apar și ajustări ale realizărilor lingvistice, împrumuturi, inovații lexicale și resemantizări. Interferența poate apărea la nivelul accentului, al pronunției, (concretizîndu-se în pronunția românească a unor cuvinte), dar şi la nivelul topicii, al structurilor gramaticale, etc. Ilustrativă este, pentru acest fapt, explicaţia de mai jos: „Dacă cineva mi-e simpatic, în percepția limbii maghiare acest lucru se exprimă prin „simpatizez cu el/ea”, în limba română însă „„1l/o simpatizez”/ „szimpatizálom őt”. Deci, dacă un vorbitor maghiar spune „Nagyon szimpatizálom ezt az embert” / „Îl simpatizez (foarte mult) pe acest om”, acest lucru nu se datorează traducerii expresiei din română în maghiară, ci, faptului că a folosit mult limba română...” (traducere personală din Szilágyi, 1996, p. 84) și i se pare mai natural, mai firesc acest mod de formulare.

Influența limbii române asupra limbii maghiare este evidentă și la nivelul lexical, unde se poate remarca ponderea semnificativă a unor cuvinte preluate (adaptate sau neadaptate) recent din limba română. Cuvintele folosite de vorbitorii maghiari în exprimarea zilnică, precum borkán, aragáz, kalorifer, punga, pix, abonament, telekománda, kalkulátor etc. sînt preluări prin care s-au constituit dublete lexicale și, deși au corespondente maghiare, vorbitorii preferă să folosească, în vorbirea de toate zilele, formele împrumutate.

Cercetările noastre efectuate (în 2012-2014) în domeniul peisajului lingvistic și al obiceiurilor de activare a limbilor în cazul persoanelor bilingve relevă faptul că lexemele registrului oficial-administrativ folosite, în special, în limba română (cum ar fi: aviz, chitanță, factură, aprobare, etc) sînt preluate și în uzul limbii maghiare. Pe baza datelor înregistrate de noi, putem releva faptul că unii vorbitori folosesc expresiile preluate din limba română chiar și atunci cînd ei consideră că nu stăpînesc foarte bine celelalte registre ale limbii.

Iată cîteva astfel de exemple:

\section{„Kértem egy csertifikátot?” / „Am cerut un certificat?" „Kedden lesz consiliu profesoral." / „Marți va fi consiliu profesoral."}

Enunțurile de mai sus ilustrează o reorganizare specifică în structura limbii de bază a vorbitorilor și se datorează contactului cu realitatea desemnată în special în/prin limba română, precum şi obiceiurilor fixate în anumite contexte de comunicare. În absența unei corespondențe sigure cu expresii din limba maternă, locutorii activează cuvintele limbii a doua.

\section{Reflecții finale}

În secțiunile lucrării de față am încercat să prezentăm diversele aspecte ale existenței bilingve, ale modului de a Fi în şi prin limbi diferite. În prezentarea fenomenelor, am pornit de la observarea praxisului comunicării, așadar, vorbitorul bilingv a constituit elementul central al examinării interferențelor.

Am considerat necesară prezentarea principalelor indicii ale profilului bilingv, deoarece cunoașterea dimensiunilor „locale” ale ansamblului de caracteristici poate permite înțelegerea mai aprofundată a fenomenului, în general. Sperăm că inventarierea manifestărilor dominante ale conduitei verbale bilingve (româno-maghiare), dincolo de notele sale specifice, poate permite desemnarea coordonatelor structurante pentru cunoașterea și descrierea altor profiluri bi(multi)lingve.

\section{Bibliografie}

Ádám, Zs. (1993). Să învățăm corect românește / Tanuljunk helyesen románul, Editura Științifică, București.

Benő, A. (2008). Kontaktológia. A nyelvi kapcsolatok alapfogalmai [Contacte interlingvistice. Conceptele de bază ale interdependențelor lingvistice], Egyetemi Mühely, Cluj-Napoca.

Corder, St. (1981). Error analysis and interlanguage, Oxford University Press, London. 
Gafton, Al. (2001). Evoluția limbii române prin traduceri biblice din secolul al XVI-lea, Editura Universității „Alexandru Ioan Cuza”, Iaşi.

Gafton, Al. (2010). Consecințele profunde ale contactelor lingvistice, în: Gh. Chivu \& O. Uță-Bărbulescu (eds.), Studii de limba română. Omagiu profesorului Grigore Brâncuş, Bucureşti, p. 77-100.

Gósy, M. (2005). Pszicholingvisztika [Psiholingvistică], Osiris, Budapesta.

Graur, A. (1968). Tendințele actuale ale limbii române, Editura Științifică, București.

Grosjean, F. (1982). Life with Two Languages. An Introcution to Bilingualism, Harvard University Press, Cambridge, MA.

Hazy, Şt. (1999). Gramatica contrastivă, Studium, Cluj-Napoca.

Horváth, I. (2008). O evaluare a politicilor de producerea a bilingvismului minoritar din România. Către o nouă problematizare, în: I. Horváth \& E.M. Todor (eds.), O evaluarea a politicilor de producere a bilingvismului, Limes, Cluj-Napoca, p. 37-60.

Nicolae, Al. \& Dragomirescu, A. (2011). 101 greșeli de lexic și de semantică, Humanitas, București.

Noica, C. (1987). Cuvânt împreună despre rostirea românească, Editura Eminescu, București.

Pamfil, A. (2000). Didactica limbii și literaturii române (pentru școlile cu predare în limbile minorităților naționale), Editura Dacia, Cluj-Napoca.

Pál, E. (2014). Considerații asupra unor maghiarisme culte în vechile traduceri româneşti, în: „Dacoromania“, XIX, nr. 1, p. 6781.

Szilágyi, N.S. (1996). Hogyan teremtsünk világot? Rávezetés a nyelvi világ vizsgálatára [Cum să fințăm lumi? Introducere în examinarea universului lingvistic], Erdélyi Tankönyvtanács, Cluj-Napoca.

Tódor, E. M. (2005). Şcoala şi alteritatea lingvistică. Contribuție la pedagogia limbii române ca ne-maternă, Casa Cărții de Ştiință, Cluj-Napoca.

Tódor, E.M. (2009). Predarea-învăţarea limbii române ca ne-maternă. O alternativă a lingvisticii aplicate, Scientia, ClujNapoca.

Weinreich, U. (2013). Limbi în contact. Constatări și probleme, traducere și cuvînt introductiv de M. Burada, Editura Universității Transilvania, Brașov.

Zafiu, R. (2010). Neglijența generalizată, în „Dilema veche”, anul VII, nr. 314, p. 10. 